\title{
Isolation of Probiotic Bacteria and Optimization of Physical and Nutrition Parameters for Bacteriocin Production
}

\author{
Subi Mathew* and Anu Augustine \\ CEPC Laboratory and Research Centre, Cashew Bhavan, Mundakkal, Kollam, Kerala, India \\ *Corresponding author
}

\begin{tabular}{|l|}
\hline Key w or d s \\
$\begin{array}{l}\text { Probiotics, Lactic acid } \\
\text { bacteria, Bacteriocin }\end{array}$ \\
\hline Article Info \\
\hline $\begin{array}{l}\text { Accepted: } \\
\text { 20 September } 2018 \\
\text { Available Online: } \\
\text { 10 October } 2018\end{array}$ \\
\hline
\end{tabular}

A B S T R A C T

The aim of this study is to analyze probiotic properties of isolated lactic acid bacteria from human breast milk. Identification of lactic acid bacterial (LAB) was done by Gram's staining and catalase test and further confirmation was based on morphological, cultural, physiological and different biochemical tests. The isolated strain was identified after different biochemical analysis which was also showed reliable probiotic properties. These isolates were examined for further probiotic properties including tolerance to bile salt and resistance to low $\mathrm{PH}$, antimicrobial activity. Probiotics are supposed to those bacteria which have beneficial effects for the host. The bacteriocin producing strains requires specific nutritional and cultural conditions for the growth and the metabolic production because the optimum growth will produce the maximum amount of metabolitesOptimization of bacteriocin production, the maximum culture density was found to be observed with starch $(2.8 \mathrm{mg} / \mathrm{ml})$. Meat extract has shown the maximum cell mass among the tested nitrogen components. The bacteriocin inhibitory activity was also found to be optimum at $1 \% \mathrm{NaCl}$ salt concentration. The bacteriocin also stable against wide range of $\mathrm{pH}$ and temperature.

\section{Introduction}

Probiotics, as defined by the Food and Agriculture Organization of United Nations (FAO) and World Health Organization (WHO) in 2001, comprise live microorganisms which, when administered in adequate amounts, confer a health benefit on the host. Probiotic products include different enzymes, vitamins, capsules or tablets and some fermented foods that contain microorganisms which have beneficial effects on the health of host. They can contain one or several species of probiotic bacteria. They are just used as health supporting products. The oral consumption of probiotic microorganisms produces a protective effect on the gut flora (Gismondo, et al., 1999, Çakır 2003, Quwehand 1999). Bacteriocins are ribosomally synthesised antimicrobial peptides produced by bacteria which have bactericidal and bacteriostatic activity against other similar and dissimilar microbials. More than $99 \%$ of bacteria can produce at least one bacteriocin, most of them are not well-known (Riley and Wertz et al., 2002). Bacteriocins are proteinaceous compounds that help to destroy closely related bacteria but also have 
an action across the species. Many current studies focus that bacteriocin production is not limited by Gram-negative bacteria. Grampositive lactic acid bacteria, a group of phylogenetically dissimilar microorganisms considered by some morphological, metabolic and physiological properties, comprise an resource for various bacteriocins that have a great possibility for industrial or medicinal applications due to the GRAS score (generally recognized as safe bacteria) of lactic acid bacteria (Abriouel et al., 2007). In addition, the bacteriocins from Gram-positive bacteria show a special inhibitory effect that is not directed against only bacteria within the same species but also against another species. Thus, the bacteriocins produced by Gram-positive bacteria possess a broader range of susceptible organism

The inhibiting and killing capacity of bacteriocin is considered as a positive method for maintain the population and decreasing the number of challengers to achieve more nutrients and living spaces in that environment. Different other antibiotics, bacteriocins are secondary metabolites and very sensitive to protease enzymes like trypsin. These are present in human beings and also therefore harmless to human body. Many bacteriocins host range is narrow, and is likely to be most effective against related bacteria with nutritive demands for the same uncommon resources (Deegan et al., 2006). Bacteriocins produced by some lactic acid bacteria, eg: nisin, salvarin, pediocinetc inhibit both closely related species and also foodborne pathogens such as Listeria monocytogenes, E.coli, Vibrio cholera, S.aureus etc. and many other spoilage bacteria (Tagg and Dajani et al., 1976). So that, bacteriocins are involved for use as natural food preservatives in juices, cheeses in recent years, this led to the discovery of ever increasing possible sources of these protein inhibitors.

\section{Materials and Methods}

\section{Isolation of lactic acid bacteria from human breast milk}

The isolation was done with human breast milk. For milk, samples were collected from the mother of $3^{\text {rd }}$ day old kid. The samples were collected in sterile bottle and stored on ice until delivery to the laboratory. Once delivered to the laboratory, they were taken to the procedure for isolation. Pour plate technique was used to isolate the organisms. Samples were used directly and also diluted to $10^{-1}, 10^{-2}$ and $10^{-3}$ using sterile distilled water. $1 \mathrm{~mL}$ of the samples and dilutions were plated into MRS agar $(\mathrm{pH}-6.3)$. The plates were incubated at $37^{\circ} \mathrm{C}$ for 3 days under aerobic conditions. After incubation, individual colonies were selected and transferred into sterile broth mediums. The following step is purifying the selected colonies with streak plate technique. The isolates were examined according to their colony morphology, catalase reaction and Grams reaction.

\section{Identification and probiotic properties of isolated organism}

\section{Gram staining}

The cultures were grown in appropriate mediums at $30^{\circ} \mathrm{C}$ for 48 hour under aerobic conditions. After incubation gram staining procedure was applied. Then under light microscopy gram positives and purified isolates were determined.

\section{Catalase test}

Catalase test was performed to isolates in order to see their catalase reactions. For this purpose, overnight cultures of isolates were grown on MRS agar at suitable conditions. After 24 hour 3\% hydrogen peroxide solution was dropped onto randomly chosen colony. 
The isolates which did not form gas bubbles, since chose. Since, LAB is known as catalase negative.

For the determination of probiotic properties of isolates three major selection criteria were choosed

Resistance to $\mathrm{pH}$

Tolerance against bile salt and

The antimicrobial activity

\section{Resistance to low pH}

Resistance to $\mathrm{pH} 3$ is often used invitro assays to determine the resistance to stomach $\mathrm{pH}$. For this purpose, active cultures (incubated for 1618 hours) were used. Cells were harvested by centrifugation for 10 minute at $500 \mathrm{rpm}$ and $4^{\circ} \mathrm{C}$. Pellets were washed out washed in phosphate - saline buffer (PBS) at pH7.2. Then cell pellets were re-suspended in PBS $(\mathrm{pH} 3)$ and incubated at $37^{\circ} \mathrm{C}$. Viable microorganisms were enumerated at the 0,1 , 2, 3 and 4 hours with pour plate techniques. Appropriate dilutions were done and plates were incubated at $37^{\circ} \mathrm{C}$ under aerobic conditions for 48 hours. Also growth was monitored at $\mathrm{OD}_{620}$. At $620 \mathrm{~nm}$ and were expressed as Colony forming units.

\section{Tolerance against bile salt}

MRS medium containing $0.3 \%$ bile (oxide) was inoculated with active cultures (incubated for 16-18 hours). During the incubation for 4 hour, viable colonies were enumerated for every hour with pour plate technique and also growth was monitored at $\mathrm{OD}_{620}$.

\section{Antimicrobial activity}

Modified agar well diffusion method was used to detect antimicrobial activities of cell free supernatant (CFS) produced from the isolates. Antibacterial activity was determined against,
Vibrio parahaemolytics, Listeria monocytogens, Vibrio cholera. All of LAB isolates were incubated for 48 hour at $37^{\circ} \mathrm{C}$. After incubation cells were removed by centrifugation.

The indicator organism is inoculated in nutrient broth and incubated at $37^{\circ} \mathrm{C}$ for $5-6$ hours. The incubated organisms swabbed on to the MHA (Muller - Hinton Agar) plates using swab and the CFS (Cell Free Supernatants) was used as antimicrobial agents. Using sterile tips the CFS was poured into the well of about $50 \mu \mathrm{L}$ and kept for incubation at $37^{\circ} \mathrm{C}$ for 24 hours. Antimicrobial activity was evaluated by measuring zone of inhibition against the test organisms

\section{Probiotic bacteria-optimisation of nutritional factors for bacteriocin production}

Bacterial culture of probiotic organism was used for evaluating effects of physical and nutritional parameters on growth and bacteriocins production. The bacterial culture was inoculated on MRS broth containing Protease peptone, beef extract, yeast extract, dextrose, tween 80 , ammonium citrate, sodium acetate, magnesium sulphate, manganese sulphate, di potassium phosphate. $\mathrm{pH}$ of the media is adjusted to 6.3 .

MRS broth was used for antimicrobial metabolite production from probiotic bacteria, $500 \mathrm{~mL}$ of conical flasks each containing 200 $\mathrm{ml}$ MRS broth autoclaved at $121^{\circ} \mathrm{C}$ for 15 minutes and inoculated with colony of a probiotic isolate grown on MRS agar. The inoculated flasks were incubated at $30^{\circ} \mathrm{C}$ for 2-3 days under stationary condition. Then centrifuged at $100 \mathrm{rpm}$ for $10 \mathrm{~min}$. Antimicrobial activity of culture supernatant $(100 \mu 1 /$ well $)$ and broth $(100 \mu 1 /$ well $)$ was tested by agar well diffusion method (Ram et al., 2013). 


\section{Quantification of cell growth}

The cell growth at each set of experiment was monitored by measuring the optical density at $620 \mathrm{~nm}$ by spectrophotometer. The samples were withdrawn at the required time of interval to measure the optical density.

\section{Quantification of protein}

Total protein of the cell free supernatant was determined by the method of Lowery et al., (1951) using Bovine Serum Albumin (BSA) as standard. The concentration of protein was calculated from the absorbance at $660 \mathrm{~nm}$. The phenolic group of tyrosine and tryptophan residues reacts with the Folin - Ciocalteau reagent and gives a blue purple colour complex, having a maximum absorption at $540 \mathrm{~nm}$. The intensity of colour is a direct function of the quantity of these amino acids present in protein.

Optimization of physical and nutrition parameters for bacteriocin production

\section{Effect of carbon sources on cell growth and bacteriocin production}

In order to evaluate the effect of different carbon sources on growth and bacteriocin production by Probiotic organism, 2\% dextrose, fructose, sucrose, starch and lactose were supplemented in MRS broth. Each flask was incubated at $30^{\circ} \mathrm{C}$ for 48 hours. The cell biomass and bacteriocins activities were determined as described previously (De Vuyst, 1995; Nelson et al., 2001).

\section{Effect of nitrogen sources on cell growth and bacteriocin production}

The effect of different nitrogen on growth and bacteriocins yield of Probiotic organism was evaluated in MRS broth supplemented with $2 \%$ nitrogenous compound. The selected nitrogen sources were, meat extract, yeast extract, tryptone and bacteriological peptone. Each flask was incubated at $30^{\circ} \mathrm{C}$ for 48 hour. The cell biomass and bacteriocin activity were determined as described previously (Verellen et al., 1998).

\section{Effect of salt concentration on cell growth and bacteriocin activity}

To evaluate the effect of salt on cell mass and bacteriocins production, Probiotic organism was inoculated into $100 \mathrm{~mL}$ MRS broth $(\mathrm{pH}-$ 6.3) supplemented with $1 \%, 2 \%, 3 \%$ and $4 \%$ $\mathrm{NaCl}$ salt concentration incubated in $30^{\circ} \mathrm{C}$ for 48 hours. The cell density, bacteriocin activity, and protein concentration were determined as described previously (Verellen et al., 1998).

\section{Effect of temperature on cell growth and antibacterial activity}

The influence of temperature on cell growth and bacteriocins activity of Probiotic organism was determined by MRS media. The cells were grown at a set of temperature $15^{0}, 30^{\circ}$, $37^{0}$ and $45^{\circ} \mathrm{C}$ for 48 hours were incubated. Biomass, protein concentration and bacteriocins activity were determined by spectrophotometer (Verellen et al., 1998; Graciella et al., 1995; Juarez et al., 2002).

\section{Effect of pH on cell growth and bacteriocin activity}

The influence of $\mathrm{PH}$ on cell growth and bacteriocins activity of Probiotic organism was determined by MRS media. The cells were grown at a set of PH 5,6,7,8 and were incubated at $30^{\circ} \mathrm{c}$ for 48 hours.

Biomass, protein concentration and bacteriocins activity were determined by spectrophotometer (Verellen et al., 1998; Graciella et al., 1995; Juarez et al., 2002). 


\section{Temperature Sensitivity}

To test the temperature sensitivity, the 48 hour culture supernatant was heated for 10 minutes at $60^{\circ} \mathrm{C}, 70{ }^{\circ} \mathrm{C}, 80^{\circ} \mathrm{C}$ and $90^{\circ} \mathrm{C}$, for that the cell free culture supernatants of the probiotic strains were chosen for the antibacterial activity test.

The sensitivity of bacteriocins at different temperature and its bacteriocins antibacterial activity was detected by agar well diffusion method against sensitivity of bacteriocins to. $V$. cholera, $V$. parahemolytics and $L$. monocytogens (Ogunbanwo et al., 2003)

\section{Results and Discussion}

Lactic acid bacteria were isolated from MRS medium at $37^{\circ} \mathrm{C}$. The catalase negative isolates were selected.

A catalase positive bacteria was also observed and they are excluded. From milk one catalase negative isolates were observed. Six of them found to be gram positive, catalase positive cocci.

\section{Probiotic properties}

\section{Resistance to low pH}

After incubation, optical density of the sample was measured at $620 \mathrm{~nm}$ and viable cell count was also determined as colony forming unit.

From which it is clear that the isolate was able to survive in $\mathrm{pH} 3$ for 4 hours. A significant increase in O.D value was observed during the interval. Hence it was concluded that the LAB isolate was tolerant to low $\mathrm{pH}$.

\section{Tolerance agaist bile salt}

The viable cells were determined by measuring O.D found to tolerate bile salt

\section{Results of antimicrobial activity}

The strains were examined according to their antimicrobial activity. For this purpose, strains were detected against the indicator microorganisms, Vibrio cholera, Vibrio parahemolytics, Listeria monocytogens.

The diameter of the inhibition zones showed that the isolates have antibacterial effect on the indicator microorganisms. The tests were done and the diameter of both crude and supernatants were obtained. For Vibrio parahaemolytics, the isolates showed large inhibition zone

In this study, Total 7 organisms were isolated from human breast milk. From that, C2 strain from human milk were selected after original characterisation and it is gram positive cocci and catalase negative and these probiotic bacteria is mainly used for further studies.

In this study the isolated strain showed the acid tolerance at $\mathrm{pH} 3$ and the bile salt tolerance at $0.3 \%$. Before reaching the intestinal tract, probiotic bacteria, must first survive transit through the stomach where the $\mathrm{pH}$ can be as low as 1.5 to 2. Bile salts are synthesised in liver from cholesterol and are secreted from the gall bladder into the duodenum. Physiological concentration of human bile from $0.1 \%-0.3 \%$

The isolated probiotic from human breast milk were strong antimicrobial activity against most of the tested enteric pathogens. This may be due to the production of bacteriocin or antibacterial compound. Antimicrobial activity of lactobacilli may be due to organic acids, hydrogen peroxide, bacteriocin or other inhibitory substances from metabolites (Todorov et al., 2010). In this study C2 showed the strongest antagonistic potential against Vibrio cholera, Listeria monocytogenes and Vibrio parahaemolyticus (Table 1-10). 
Table.1

\begin{tabular}{|c|c|c|c|c|}
\hline SAMPLES & ISOLATES & GRAM STAINING & CATALASE TEST & COLONY MORPHOLOGY \\
\hline \multirow[t]{7}{*}{ milk } & $\mathrm{C} 1$ & + ve, cocci & - ve & Cream colour, pinpoint transparent colonies \\
\hline & $\mathrm{C} 2$ & +ve,cocci & $-\mathrm{ve}$ & Cream colour, small round colonies \\
\hline & $\mathrm{C} 3$ & $+\mathrm{ve}$, cocci & $+\mathrm{ve}$ & White colour, small colonies \\
\hline & $\mathrm{C} 4$ & $+\mathrm{ve}$, cocci & $+\mathrm{ve}$ & Small, round, transparent colonies \\
\hline & C5 & $+\mathrm{ve}$, cocci & + ve & Cream colour, large round colonies \\
\hline & C6 & $+\mathrm{ve}$, cocci & $+\mathrm{ve}$ & Small, white, opaque colonies \\
\hline & $\mathrm{C} 7$ & $+\mathrm{ve}$, cocci & $+\mathrm{ve}$ & Small, white colour, flat colonies \\
\hline
\end{tabular}

Table.2

\begin{tabular}{|l|}
\hline HOURS \\
\hline $0^{\text {th }}$ hour \\
\hline $1^{\text {st }}$ hour \\
\hline $2^{\text {nd }}$ hour \\
\hline $3^{\text {rd }}$ hour \\
\hline $4^{\text {th }}$ hour \\
\hline
\end{tabular}

ב

\section{OD at $620 \mathrm{~nm}$}

0.532

0.541

0.567

0.571

0.542

\section{CFU per ml}

TNTC

TNTC

TNTC

TNTC

TNTC

Table.3

\begin{tabular}{|l|}
\hline HOURS \\
\hline $0^{\text {th }}$ hour \\
\hline $1^{\text {st }}$ hour \\
\hline $2^{\text {nd }}$ hour \\
\hline $3^{\text {rd }}$ hour \\
\hline $4^{\text {th }}$ hour \\
\hline
\end{tabular}

\begin{tabular}{|c|c|}
\hline O.D at $620 \mathbf{n m}$ & CFU per $\mathbf{~ m l}$ \\
\hline 0.025 & TNTC \\
\hline 0.075 & TNTC \\
\hline 0.192 & TNTC \\
\hline 0.487 & TNTC \\
\hline 1.001 & TNTC \\
\hline
\end{tabular}

Table.4

\begin{tabular}{|l|}
\hline ORGANISMS \\
\hline Vibrio parahaemolytics \\
\hline Listeria monocytogens \\
\hline Vibrio cholerae \\
\hline
\end{tabular}

\begin{tabular}{|c|c|}
\hline \multicolumn{2}{|c|}{ ZONE OF INHIBITION } \\
\hline CRUDE & SUPERNATENT \\
\hline $16 \mathrm{~mm}$ & $16 \mathrm{~mm}$ \\
\hline $13 \mathrm{~mm}$ & $14 \mathrm{~mm}$ \\
\hline $12 \mathrm{~mm}$ & $13 \mathrm{~mm}$ \\
\hline
\end{tabular}

Table.5

\begin{tabular}{|c|c|c|c|c|c|}
\hline CARBON SOURCES & Mg/mL & \multicolumn{2}{|c|}{$\begin{array}{c}\text { ANTI - BACTERIAL ACTIVITY (Against - } \\
\text { pathogenic organisms) }\end{array}$} & $\begin{array}{c}\text { CELL } \\
\text { GROWTH }\end{array}$ \\
& $\begin{array}{c}\text { O.D. at } \\
540 \mathrm{~nm}\end{array}$ & V. cholera & V. parahaemolytics & L. monocytogens & $\begin{array}{c}\text { O.D. at } \\
620 \mathrm{~nm}\end{array}$ \\
\hline Fructose & 4.723 & $10 \mathrm{~mm}$ & $16 \mathrm{~mm}$ & $15 \mathrm{~mm}$ & 1.508 \\
\hline Sucrose & 4.949 & $12 \mathrm{~mm}$ & $19 \mathrm{~mm}$ & 20 & 1.743 \\
\hline Lactose & 4.811 & $13 \mathrm{~mm}$ & $20 \mathrm{~mm}$ & $12 \mathrm{~mm}$ & 1.702 \\
\hline Starch & 4.789 & $11 \mathrm{~mm}$ & $18 \mathrm{~mm}$ & $15 \mathrm{~mm}$ & 2.846 \\
\hline
\end{tabular}


Table.6 Effect and influence of nitrogen sources on growth and bacteriocin production

\begin{tabular}{|c|c|c|c|c|c|}
\hline $\begin{array}{c}\text { NTROGEN } \\
\text { SOURCES }\end{array}$ & Mg/mL & \multicolumn{2}{|c|}{$\begin{array}{c}\text { ANTI - BACTERIAL ACTIVITY (Against - } \\
\text { pathogenic organisms) }\end{array}$} & $\begin{array}{c}\text { O.D. at } \\
620 \mathrm{~nm}\end{array}$ \\
\cline { 2 - 7 } & $\begin{array}{c}\text { O.D. at } \\
540 \mathrm{~nm}\end{array}$ & $\begin{array}{c}\text { V. } \\
\text { cholera }\end{array}$ & V. parahaemolytics & L. monocytogens & $\begin{array}{c}\text { O.D. at } \\
620 \mathrm{~nm}\end{array}$ \\
\hline Yeast extract & 4.566 & Nil & $17 \mathrm{~mm}$ & $22 \mathrm{~mm}$ & 2.149 \\
\hline Meat extract & 4.947 & Nil & $28 \mathrm{~mm}$ & $22 \mathrm{~mm}$ & 2.939 \\
\hline Tryptone & 4.833 & Nil & $20 \mathrm{~mm}$ & $21 \mathrm{~mm}$ & 2.357 \\
\hline Peptone & 4.850 & Nil & $18 \mathrm{~mm}$ & $27 \mathrm{~mm}$ & 2.275 \\
\hline
\end{tabular}

Table.7 Effect and influence of $\mathrm{NaCl}$ concentration on growth and bacteriocin production

\begin{tabular}{|c|c|c|c|c|c|}
\hline $\begin{array}{c}\text { NaCl } \\
\text { CONCENTRTION }\end{array}$ & Mg/mL & \multicolumn{2}{|c|}{$\begin{array}{c}\text { ANTI - BACTERIAL ACTIVITY (Against - } \\
\text { pathogenic organisms) }\end{array}$} & $\begin{array}{c}\text { CELL } \\
\text { GROWTH }\end{array}$ \\
\hline & & $\begin{array}{c}\text { V. } \\
\text { cholera }\end{array}$ & V. parahaemolytics & L. monocytogens & $\begin{array}{c}\text { O.D. at } \\
620 \mathrm{~nm}\end{array}$ \\
\hline $1 \%$ & 4.069 & $\mathrm{Nil}$ & $15 \mathrm{~mm}$ & $13 \mathrm{~mm}$ & 1.615 \\
\hline $2 \%$ & 3.909 & $\mathrm{Nil}$ & $14 \mathrm{~mm}$ & $17 \mathrm{~mm}$ & 1.476 \\
\hline $3 \%$ & 3.924 & $\mathrm{Nil}$ & $18 \mathrm{~mm}$ & $18 \mathrm{~mm}$ & 1.425 \\
\hline $4 \%$ & 3.918 & $\mathrm{Nil}$ & $14 \mathrm{~mm}$ & $16 \mathrm{~mm}$ & 1.381 \\
\hline
\end{tabular}

Table.8 Effect and influence of temperatures on growth and bacteriocin production

\begin{tabular}{|c|} 
DIFFERENT \\
TEMPERATURE \\
\hline CONCENTRTION \\
\hline 150C \\
\hline $300 \mathrm{C}$ \\
\hline $370 \mathrm{C}$ \\
\hline $450 \mathrm{C}$ \\
\hline
\end{tabular}

\begin{tabular}{|c|c|c|c|c|}
\hline Mg/mL & \multicolumn{2}{|c|}{$\begin{array}{c}\text { ANTI - BACTERIAL ACTIVITY (Against - } \\
\text { pathogenic organisms) }\end{array}$} & $\begin{array}{c}\text { CELL } \\
\text { GROWTH }\end{array}$ \\
\cline { 2 - 5 } & $\begin{array}{c}V . \\
\text { cholera }\end{array}$ & V. parahaemolytics & L. monocytogens & $\begin{array}{c}\text { O.D. at } \\
620 \mathrm{~nm}\end{array}$ \\
\hline 3.984 & $12 \mathrm{~mm}$ & $14 \mathrm{~mm}$ & $12 \mathrm{~mm}$ & 1.660 \\
\hline 4.550 & $14 \mathrm{~mm}$ & $15 \mathrm{~mm}$ & $14 \mathrm{~mm}$ & 1.812 \\
\hline 3.993 & $13 \mathrm{~mm}$ & $10 \mathrm{~mm}$ & $10 \mathrm{~mm}$ & 1.762 \\
\hline $4 . .037$ & $10 \mathrm{~mm}$ & $10 \mathrm{~mm}$ & $11 \mathrm{~mm}$ & 1.250 \\
\hline
\end{tabular}

Table.9 Effect and influence of $\mathrm{pH}$ on growth and bacteriocin production

\begin{tabular}{|c|c|c|c|c|c|}
\hline $\begin{array}{c}\text { DIFFERENT pH } \\
\text { CONCENTRTION }\end{array}$ & Mg/mL & \multicolumn{2}{|c|}{$\begin{array}{c}\text { ANTI - BACTERIAL ACTIVITY (Against - } \\
\text { pathogenic organisms) }\end{array}$} & $\begin{array}{c}\text { CELL } \\
\text { GROWTH }\end{array}$ \\
\cline { 3 - 6 } & & $\begin{array}{c}\text { V. } \\
\text { cholera }\end{array}$ & $\begin{array}{c}\text { V. } \\
\text { parahaemolytics }\end{array}$ & $\begin{array}{c}\text { L. } \\
\text { monocytogens }\end{array}$ & $\begin{array}{c}\text { O.D.at } \\
620 \mathrm{~nm}\end{array}$ \\
\hline pH 5 & 4.358 & Nil & $11 \mathrm{~mm}$ & $18 \mathrm{~mm}$ & 0.760 \\
\hline pH 6 & 5.206 & Nil & $14 \mathrm{~mm}$ & $15 \mathrm{~mm}$ & 2.01 \\
\hline pH 7 & 4.844 & Nil & $12 \mathrm{~mm}$ & $16 \mathrm{~mm}$ & 2.030 \\
\hline pH 8 & 4.075 & Nil & $10 \mathrm{~mm}$ & $13 \mathrm{~mm}$ & 1.467 \\
\hline
\end{tabular}


Table.10 Temperature sensitivity

\begin{tabular}{|c|c|c|c|}
\hline \multirow{2}{*}{$\begin{array}{c}\text { DIFFERENT } \\
\text { TEMPERATURE }\end{array}$} & \multicolumn{2}{|c|}{ ANTI - BACTERIAL ACTIVITY (Against -pathogenic organisms) } \\
\hline V. cholera & V. parahaemolytics & L. monocytogens \\
\hline $600 \mathrm{C}$ & Nil & $15 \mathrm{~mm}$ & $10 \mathrm{~mm}$ \\
\hline $700 \mathrm{C}$ & Nil & $20 \mathrm{~mm}$ & $12 \mathrm{~mm}$ \\
\hline $800 \mathrm{C}$ & Nil & $18 \mathrm{~mm}$ & $13 \mathrm{~mm}$ \\
\hline $900 \mathrm{C}$ & Nil & $18 \mathrm{~mm}$ & $13 \mathrm{~mm}$ \\
\hline
\end{tabular}

Effect and influence of carbon sources on growth and bacteriocin production

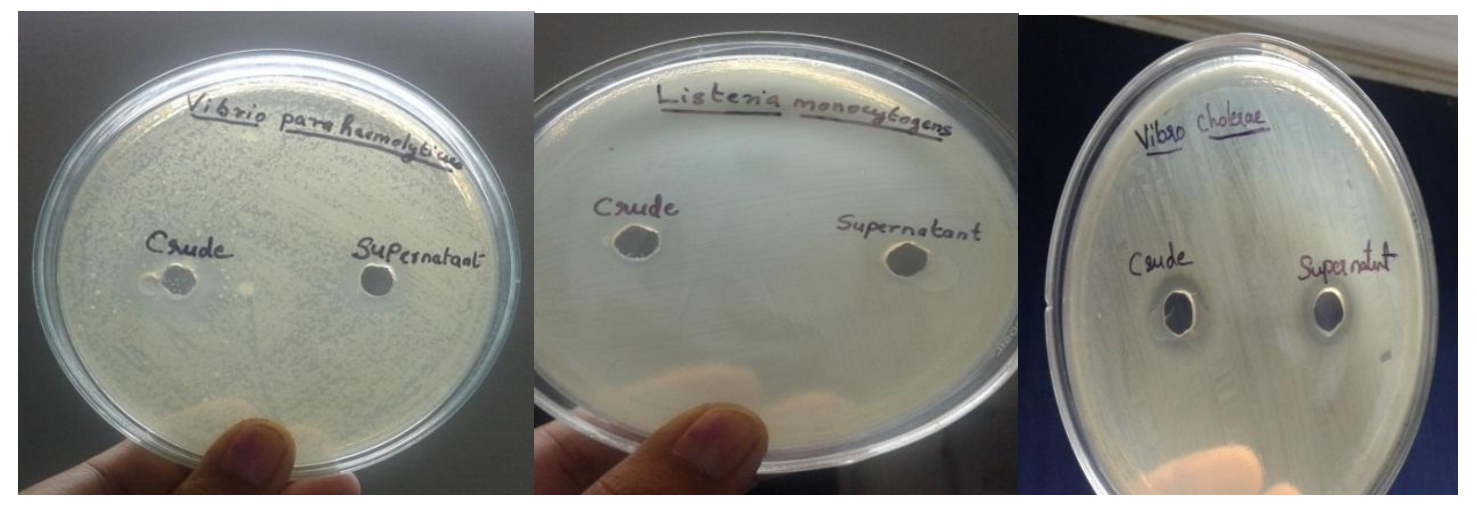

Obadina et al., (2006) also reported that fermentation process, which involved $L$. plantarum, had a broad antimicrobial inhibitory spectrum, against Salmonella typhi, E.coli, and S.aureus. Hence, isolated probiotics can be useful to prevent enteric infections such as diarrhoea, dysentery, typhoid, food poisoning etc.

The probiotic strains produce many inhibitory substances with bactericidal or a bacteriolytic activity. Main objective of this project is the optimization of physical and nutritional parameters of bacteriocins produced by probiotic bacteria. These results indicate that bacteriocin acts bacteriocidally rather than bacteriostatic ally on sensitive cells.

The nature of carbon sources also directly influences the growth and bacteriocin yield of probiotic strain. The maximum culture density was found to be observed with starch. However, growth of bacteria with sucrose and lactose was found almost similar. Todorov et al., (2004, 2005) proved that, a Latic acid bacteria a strain isolated from goat milk, has been shown to increase the yield of bacteriocin with up to $2 \%$ supplement of starch.

Nitrogen source is another important nutritional supplement required for growth and bacteriocin production. Each evaluated nitrogenous source has shown a differential effect on growth, however, each nitrogen source has supported the growth and the bacteriocins production. The meat extract has shown the maximum cell mass among the tested nitrogen components. The tryptone and peptone provided second best factor contributing growth and bacteriocin yield, which is followed by yeast extract.

These influence of nitrogen sources on bacteriocin activity, showed a linear relationship with cell mass and bacteriocin production. A variable effect of meat extract, tryptone and peptone on growth and 
bacteriocin production of many Bacilli has been evaluated (Nel et al., 2001; Lee et al., 2012). A high level of bacteriocin production has been observed with MRS broth supplemented with peptone while reducing levels of biomass with this combination was observed (Lee et al., 2012).

In this experiment, the maximum growth of isolated cell was recorded with $1 \% \mathrm{NaCl}$ concentration. The bacteriocin inhibitory activity was also found to be optimum at $1 \%$ $\mathrm{NaCl}$ salt concentration. However, the least cell biomass and bacteriocin production were observed at $2 \%$ and $4 \% \mathrm{NaCl}$ concentration $\mathrm{OD}_{540}$ and $620 \mathrm{~nm}$. This experimental feature on cell growth and bacteriocin activity, further support the growth associated bacteriocin production as it was observed with other performed culture parameter. The best growth of isolated strain was found to be maximum at the $1 \%$ and $3 \% \mathrm{NaCl}$ concentration. The optimum bacteriocin activity with 1- $3 \%$ $\mathrm{NaCl}$ concentration has been previously reported (Palanisamy et al., 2013).

Among the conducted set of $\mathrm{pH}$ experiments, the optimum inhibitory of probiotic strain was observed in the range of $\mathrm{pH} 6-7$. The maximum amount of bacteriocin was found to be produced nearly at $\mathrm{pH} 6$. However, further increased in $\mathrm{pH} \mathrm{7,} \mathrm{the} \mathrm{bacteriocin} \mathrm{production}$ was found to be militated against Vibrio parahaemolytics. The least biomass and bacteriocin yield were observed at $\mathrm{pH} 5$ and $\mathrm{pH}$ 8. These finding suggested that bacteriocin production increased near the optimum condition of temperature and $\mathrm{pH}$, but highly specific to producer strain.

The effect of temperature on cell growth and bacteriocin production from probiotic bacteria was found to be observed from $15-40^{\circ} \mathrm{C}$ and it was optimized at $30^{\circ} \mathrm{C}$. The bacteriocin activity was found to be reduced after $15^{\circ} \mathrm{C}$. These Result indicated that optimum level of bacteriocin was associated with an optimum temperature of growth. The growth associated optimum bacteriocin production at $30^{\circ} \mathrm{C}$ from Vibrio parahaemolytics, Vibrio cholera has been reported (Palanisamy et al., 2013; Juarez et al., 2002).

Yang et al., (2012) reported that the lactic acid bacteria were thermally stable at $60^{\circ} \mathrm{C}$, $70^{\circ} \mathrm{C}, 80^{\circ} \mathrm{C}$ and $90^{\circ} \mathrm{C}$ for 10 minutes. In this study, the activity of these compounds were significantly maintained their activity by boiling for 10 minutes, which indicates that the antimicrobial activity of the culture supernatant is heat-resistant to $v$. cholera and sensitive to $V$. parahaemolytics and $L$. monocytogens.

The study concluded that the isolated probiotic C2 strain from human milk meet several of the probiotic criteria, which includes acid and bile tolerances, as well as the production of antimicrobial substances. These characteristics may be advantageous for a probiotic culture to be successful in colonizing and compete with pathogens in gastrointestinal environment. The ability of these isolates to survive in acidic conditions, bile resistance, and the production of bacteriocin that is active against enteric pathogens and useful in prevention of enteric infections. These bacteriocins were also stable over a wide range of $\mathrm{pH}$, temperature and heat. This heat, temperature and $\mathrm{pH}$ stability may be useful if the bacteriocin is to be used as an antimicrobial agent in fermented foods or thermally processed foods. Thus, these probiotic strains could be used for both preventive and therapeutic purpose in controlling intestinal infection

\section{References}

Cakır, İ. (2003). Determination of some probiotic properties on Lactobacilli and Bifidobacteria. Ankara University 
Thesis of Ph.D. Cardinal, M.J., Meghrous, J., Lacroix, C., Simard, R.E., 1997. Isolation of Lactococcus lactis strain producing inhibitory activity against Listeria. Food Biotechnology 11:129.

De Vuyst, L., (1995), -Nutritional factors affecting nisin production by Lactococcus lactis subsp. lactis NIZO 22186 in a synthetic mediuml, $J$ ApplBacteriol, 78, 28-33.

Gismondo MR, Drago, L Lambardi A. (1999). Review of probiotics available to modify gastrointestinal flora. international journal of antimicrobial agents 12:287-292.

Nelson, P. G, M Luisa, R., Lorenzo, P., (2001), - Nutritional factors affecting the production of two bacteriocins from lactic acid bacteria on wheyll, Int J Food Microbiol,70, 267-281.

Ogunbanwo, S., Sanni, A. and Onilude, A., (2003). Influence of cultural conditions on the production of bacteriocins by Lactobacillus brevisOG1. Afri. J. Biotechnol., 2(7), 179-184.

Palanisamy, I., Thirumalai M., (2013), -Optimization of bacteriocin production by Lactobacillus sp\|, Aquatic Biosystems, 9, 1- 12.

Quwehand, A.C., Kirjavainen, P.V., Shortt, C., Salminen, S. (1999). Probiotics: Mechanisms and established effects. International Dairy Journal 9:43-52.

Riley M.A., and Wertz J.E. BACTERIOCINS: Evolution, Ecology, and Application. Annual Reviews in Microbiology. (2002); 56:117-137.Tagg JR., Dajani AS., Wannamaker LW (1976); Bacteriocins of gram positive bacteria. Bacteriol. Rev 40. 722 - 756.

Todorov S.D., Dicks, L.M.T., (2004), -Effect of medium components on bacteriocin production by Lactobacillus pentosus $S T 151 \mathrm{BR}$, a strain isolated from beer produced by fermentation of maize, barley and soy flourl, World $J$ Microbiol Biotechnol, 20, 643-650

Verellen, T.L.J., Bruggenan, G., van Reenen, C.A., Dicks., L.M.T., Vandamme, E.J.,(1998), -Fermentation optimization of plataricin 423, a bacteriocin produced by Lactobacillus plantarum423, J Ferment Bioeng\|, 86, 174-17

\section{How to cite this article:}

Subi Mathew and Anu Augustine. 2018. Isolation of Probiotic Bacteria and Optimization of Physical and Nutrition Parameters for Bacteriocin Production. Int.J.Curr.Microbiol.App.Sci. 7(10): 2717-2726. doi: https://doi.org/10.20546/ijcmas.2018.710.316 